\title{
Politics, Poetics and "the Tragedy of Existence". The reception of Młyny Bozie [the Mills of God] Novel Series by Kazimierz Truchanowski by the Censorship Bureau
}

The reception of the Mtyny Boże novel series by Kazimierz Truchanowski, written over twelve years ${ }^{1}$ and, it seems, designed to be a masterpiece and strongly rooted in modernistic and Young Poland traditions, was mixed. Some critics saw it as a grand work; others perceived it as being old-fashion, naive in its supposed philosophical nature, wordy or even talentless, and epigonic ${ }^{2}$. Today the dispute seems to be both settled and unimportant. A few papers and books on the history of literature devoted to Truchanowski that have appeared in recent years, may not be a lot but it is still a considerable number considering that the author of

* Dr, e-mail: kajkeron@wp.pl; Institute of Literary Research, Polish Academy of Sciences, 00-330 Warszawa, ul. Nowy Świat 72.

${ }^{1}$ The Mills of God included five volumes: Niepokój, Tyranie and Zdejmowanie masek (1961, 1963 and 1965), Piekło nie zna snu (1967), and Zatrzaśnięcie bram (1973).

${ }^{2}$ In their analysis of Truchanowski's prose, some scholars (Ryszard Chodźko, Jakub Lichański), not only defended it from the accusation of being derivative, but also placed it in such a multitude of literary contexts and cultural references that they, intentionally or not, boosted its artistic significance; they seemed at times to treat him as an equal literary partner to Kafka, Mann, Musil, and Schulz. Vide J.Z. Lichański, Kazimierz Truchanowski. Człowiek, pisarz, myśliciel, in: Przymierzanie masek, p. 224; R. Chodźko, Pejzaże świadomości. Powieściopisarstwo Kazimierza Truchanowskiego, Białystok 1980, p. 40 et al.

Texts by Jan Koprowski, Bogusław Gryszkiewicz and Jerzy Ficowski were completely different in tone. They denied Truchanowski's work artistic value by pointing to its slave-like dependence on Schultz's prose; the lack of internal logic, mannerism, old-fashioned style, cliché imagery, dullness of descriptions and trivial intellectual reflection. cf. the convincing text by Jan Koprowski (Arcydzieło czy mistyfikacja, "Twórczość" 1962, vol. 21, p. 141, 143). See B. Gryszkiewicz, Adam i panienki. Treści fantazmatyczne w "Zatrutych studniach” Kazimierza Truchanowskiego, in: Przymierzanie masek, pp. 149, 156. Jerzy Ficowski wrote about the epigonistic character of Truchanowski's prose, particularly early prose, and its debt to Schultz in an article with a telling title Własnowidz i cudotwórca czyli "Ulica Krokodyli" i "Ulica Wszystkich Świętych" ("Kresy” 1996, vol. 2, pp. 61-73). Ficowski argued that Truchanowski's prose was a kind of a cryptomnesia, or unconscious plagiarism. He supported his claims with multiple comparisons of Truchanowski's and Schultz's works. 
Mtyny Boże and Zatrute Studnie [Poisoned Wells] has been virtually forgotten by readers. It could be said that Truchanowski's prose is interesting not as much on its own, but rather as a subject of study, as a kind of literary peculiarity or a special case of Polish $20^{\text {th }}$-century literature.

The following text will be devoted to the reception of Mtyny Boże by the censorship bureau. The documents which have survived from the Chief Control Bureau include the reviews of three subsequent volumes of the series (including three extensive reviews of the first volume). The material does not reveal anything new about Truchanowski's prose - censor interventions were minimal in that case. However, as a proof of censors' perception of his prose, it is paradoxically interesting. Once again: not so much due to its artistic value, but as an intriguing case of the history of literature, allowing us to formulate some conclusions regarding the mechanisms of censorship. Truchanowski's vast, hermetic series, difficult to understand, was read in the Control Bureau with a surprising amount of attention and gravity, at least at the beginning. Subsequent parts of the ambitious work met with less attention by the officers. Censors' reviews of the series, composed in the 1960s, provide an interesting view of the growing tolerance, and indifference, to such difficult, non-epic, and hermetic prose: surely far from official national cultural-ideological concept, and at the same time not in open conflict with it. The fate of Mtyny Boże could be interpreted as an introduction to the so-called "socparnasizm" [Socialist parnassism] or as a short course on the history of the growing pragmatism of the Control Bureau. Therefore, it is worth looking closely at that meeting of this hermetic, "artistic" prose with censorship.

* * *

Niepokój [Anxiety], the first volume of Mtyny Boże, received three detailed reviews. Censors approached Truchanowski's prose with utmost gravity and, despite ideological reservations, evaluated it highly for its artistic qualities. In the first review, an officer of the GUKPPiW (Main Office of Control of Press, Publications and Shows) tried to reconstruct the poetics of the work. But, above all, while overcoming a kind of helplessness regarding the elaborate symbolism of the work, she tried to define its political undertone and carefully assess the dangers its publication could have posed.

The hermetic nature of Truchanowski's novels proved to be a critical issue. The high complexity of the imagery, symbolic saturation and the grotesque distortion of reality caused many problems for the censors. The difficulty in perceiving the work and its indecypherability surely were not only or even mainly a result of anti-censorship strategies but rather a result of the employed poetics, rooted in expressionistic and Young Polish patterns, which Truchanowski developed mostly in the 1930s. That hermeticism proved, however, at least up to a certain point, 
troublesome for censorship based on the principle that anything that was vague, was potentially dangerous:

Thus, logically speaking, the image of an individual and the society in Młyny Boże is an image of our times. I do not want to discuss whether courts, or "Mills of opinions and courts" are a reflection of the Central Committee or the UB [Urząd Bezpieczeństwa - Secret Service] since it leads nowhere. It is impossible to decipher all the symbols and allusions gathered on several hundred pages. One thing is clear to me - it is a vision of a lost individual, helpless against all-powerful and apocalyptic social institutions. (...) We can, therefore, read this novel as an image of "the period of errors and deformation" with the positive post-October ending. (...) I feel the author, by providing us with this grim picture of our reality, wanted to express (especially in its ending) that he accepts it as a kind of stage in historical development (and pessimism is pan-human because people are insignificant, etc.) (...) The final pages of the book contain passages showing a clear, in my opinion, approval of our government, despite the fact that it is full of resignation (p. 544, 547)

The lack of consistency in recreating the author's attitude towards the government (approving, but full of resignation and pessimism) was quite clear. It mainly resulted from the semantic vagueness and the general nature of the imagery (allowing for free interpretation) of the novel itself. Eventually, the reviewer decided that the novel was not politically dangerous and she settled her numerous reservations according to the pragmatic rule of hermetic content being harmless:

I believe we should issue the permit for the printing of this novel. The book will be inaccessible to the general audience, A philosophical book and the reactions to it will surely be insignificant. Still, I must confirm its extremely high literary value. Surely, it is not socially positive, but it cannot cause any damage. Possible minute interventions: p. 289 (usurpation of power) and p. 428 (tighten the screws on people) ${ }^{4}$.

The second censor also confirmed the "literary value of the book," but he noted that the artistic quality "cannot mask possible political damage" the novel could cause. He proposed to re-edit the text in the "instances concerning the issue of gov-

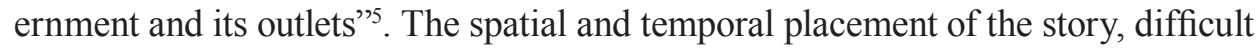
in the case of such a complex novel, detached from historical events, and designed as one big metaphor, seems crucial for deciphering the undertone of the book.

${ }^{3}$ AAN, GUKPPiW, ref. no. 643 (68/57), 1. 90; review by Renata Światycka, bearing a note: "I spoke to comrade Wichowa and we decided that we will get back to the book". The rest illegible.

${ }^{4}$ Ibidem.

${ }^{5}$ AAN, GUKPPiW, ref. no. 643 (68/57), 1. 94. I. Szlajfer, 30.01.1961. 
Due to the complicated structure of the book, it causes some difficulties in correct reading of the content. They stem from the fact that the story is set in an unspecified timeframe, somewhat timeless. There is no real physical location, and there are no details that could indicate the social system in which the action takes place. Those are, however, difficulties only at first glance. The themes covered start to take shape while delving into the book. The work is also full of illusions (sic!) and digressions, there are many allegoric images and it is full of rhetoric, sumbolism, and possible solutions. It seems that this (com)position and that method of expression fits the author best. Still, the main problems are traceable and can be referred to. (...) The above-mentioned views of the author on the most important issues raised in the novel clearly specify its non-Marxist philosophical content. Regardless whether the novel applies to the present or not, the problems it contains are still problems. In my opinion, the work is contemporary. The passages on the discovery of the atom, Sputnikrockets, and the threats of war support this claim. Many of the themes may be allusions to the relations of the socialist reality. If we consider the fact that we do not live in an abstract, but rather a world of real structure of social powers, and that the novel was published in the Polish People's Republic, we cannot ignore how it might be received. All thinking readers will ask themselves, for example, whether the model of power, as presented in the book, is a kind of satire on our reality or not ${ }^{6}$.

Quite clearly the second censor was stricter in his evaluation: the transfer of complicated poetics to philosophical and political ideas did not reduce the level of his suspiciousness and the need to settle the differences between the philosophy of the novel and the state doctrine.

The third review, by the same author and dated 17 June 1960, was interesting because it was proof of negotiations between the author and the bureau. Unfortunately, the author's letter to the bureau has not survived, at least in the censorship's archives. It might have shed some light on his strategy for dealing with censorship. In reply to that unknown letter, the censor wrote another review, addressing Truchanowski's remarks. Interestingly enough, he retained his "educational" approach, but, based on the author's explanations, he was willing to withdraw his previous decisions and accept his error. Perhaps some kind of a hidden motivation (the decision of a ranking officer or support for Truchanowski) could had been hidden behind that change of perspective. That cannot be excluded. However, the favourable, conciliatory and mildly educational tone of the second review seemed to be characteristic of censorship at the time. A censor was not so much meant to oversee and punish, as gently direct to the correct path:

\footnotetext{
${ }^{6}$ Ibidem.
} 
Upon the second reading of the second part of the book, I can see the logic of its structure more clearly than before and I am not surprised that the Author did not accept my previous remarks about the structure. I still believe that some things could be put in a (much) more concise fashion. However, with the used narrative in mind, specific for the Author's works in general, it could be difficult to introduce those changes. Where the basic structural notions are concerned, however, the Author has had the advantage over me of knowing the plan for his full work, whereas I can only speculate with almost no suggestions.

(...) I understood all that was unclear and confusing previously, i.e., the placement of the novel in time. In fact, I should have guessed it sooner. All it took was to remind myself the Author's year of birth and the area of his experiences as a young man in order to realise that associating intellectual experiences of a young man with modern times was not possible. I made an error, caused probably by the current obsessions of youth literature rather than by Truchanowski's text. A careful reading of the text clearly shows that the author moves among categories from a few decades ago. (...) His city is one of the 1920s (or older). It is quiet, with no noisy transportation and communications systems. Even the organisation and the work system of courts, despite the red and green lights, resembles something akin to the pre-WWII tax office ${ }^{7}$.

Apparently, the issue of the placement of the content of Mtyny Boze in time was crucial in the dispute with the author and for the entire publishing history of the novel.

It seems extremely interesting that the critical criterion for solving the problems of temporal and spatial placement of the events was not, surprisingly, the supposed reaction of the reader, reconstructed on the basis of the interpretation of the text, but the intent of the author, used, apparently, somewhat naively: based on the author's declaration.

"Such discussions may seem amusing,", the censor wrote, "but ultimately they are meant for something crucial: deciphering the Author's intent, hidden underneath the network of imagery".

And then he concluded:

It seems that, according to the assumptions used by the author, the work is logically structured and clear and, at the same time, it does not allow any interpretations contrary to his intentions, despite the planned ambiguity ${ }^{8}$.

\footnotetext{
${ }^{7}$ Review no. 3, dated 17 VI 1960. Ibidem, c. 96.

${ }^{8}$ Ibidem.
} 
The author's comments, i.e. the author's autointerpretation during his exchange with censors, but also the prefaces and afterwords to the novel, played a significant role. It was, in fact, a part of a broader phenomenon. Censors paid much attention to the commentary which indicated how a given work should be read, especially in the case of Western literature translated into Polish. The extratextual interpretation cues could have also been important in the case of metaphoric works using the poetics of grotesque allegory or parable. Ambiguity resulting from the poetics employed in the work made the extra-textual suggestions directing the reading decisive when the fate of individual works was concerned ${ }^{9}$. Then again, Truchanowski's comments were as vague as the novel itself ${ }^{10}$.

The reliance on the author's commentary may seem surprising, even more so as the same censor correctly noted in his first review that many problems raised by Truchanowski were quite contemporary (the issues of the atom, etc.), and yet the novel was placed as timeles, which enabled the free interpretation of its critical acuteness. Still, the conciliatory, yielding tone of the censor was meant to be only a customary gesture to cover some very pragmatic effects. Ultimately, author's declarations expressed in his letters to the censorship bureau had to be "backed" with appropriate in-text changes. The review quoted before attested to that:

The Author's corrections to one of the most important chapters (...) clearly suggest that it was not about satire on bureaucracy or contemporary satire at all. The Author meant to raise more general issues. The entire book is a depiction of a young person's intellectual experiences. (...) I have to go to Canossa and absolve the Author of sins he did not commit: the second part does not contain a hidden squib on "the times past". The entire story has to be referred to more general issues, a period historical closed for us ${ }^{11}$.

${ }^{9}$ For example, the fictional preface to Lem's Ksiega Robotów, which was a part of the work itself, was considered by the censor as a reason to become less suspicious and as encouragement to take it "with a pinch of salt". Jak szukaliśmy Lailonii, an opening story for Kołakowski's fairy tales (1960s) also seemed to have a strong significance for the censors since it suggests universal meaning of those stories.

${ }^{10}$ The author himself remarked in the preface: "A work, when it is complete and leaves the writer's study, should not, in my opinion, bear any trace of author recommendations in the form of the so-called introductions or afterwords. The text should speak for itself. Yet, there are situations when a preface is necessary. That is the case with Mtyny Boże. (...) I tried to show universal problems in all three volumes - problems that preoccupy human minds. Even though they are mostly constant, current and crucial for each generation, it can be easily seen that the events depicted in Book 1 (Niepokój) apply to the period before, during and after the World War I. The $2^{\text {nd }}$ Book (Tyranie) depicts events during the World War II. In Book 3 (Zdejmowanie masek) make Adam, the main protagonist, face the contemporary problems and conflicts". (K. Truchanowski, Stowo wstepne, in: Niepokój, Warsaw 1961, pp. 5-6).

${ }^{11}$ AAN, GUKPPiW, ref. no. 643 (68/57), 1. 96. 
The "Author's absolution" and the polite approval of the novel seemed a denial of any considerable importance. In the conclusion to his review, the censor formulated a peculiar and ambiguous conclusion:

I believe that if Truchanowski ever reaches our times, it will not be earlier than in part three. We have enough time, then ${ }^{12}$.

That strange remark (it is unclear whether it should be understood in the context of the author's age, political changes or the expected influence of state ideology on the society) was the first sign of Truchanowski's neglect, became fully visible in the reviews of the remaining two novels. The second and third parts of the series received only one review each and were handled much more briefly. It was explained by the censor's (Renata Światycka) conviction that the artistic value of subsequent volumes was dropping and her increasingly stronger impatience to read the difficult book. The following is a fragment of a review of Tyranie from 1963:

[The volume - K.M.] is a huge drop of quality. Niepokój was difficult but fascinating. Tyranie is a rock one cannot dig through. In fact, the entire book (all 457 pages) is reduced to a commentary of the first volume. The author dwells on the same issues concerning Adam's stay in the city, Courts, the Theatre, etc. (...) This work has, in my opinion, no value. Still, there are no censorship reservations ${ }^{13}$.

Also in the case of the third volume, Zdejmowanie masek (1965), the problem of the plot's placement in time proved to be a key issue. The reviewer noted that in the preface to volume 1, the author said the third volume of Mlyny Boże would be devoted to contemporary times while in the afterword to volume 3 he explained that the material had grown so much that the overall concept had to be changed: "I shall attempt to depict life and its changes in our times in a new novel series which will be entitled Mechanizmy [Mechanisms]," Truchanowski stated. The author of the review commented:

So, contrary to numerous declarations about the content of the third volume, the author still refers to the past. In terms of the main theme and atmosphere of the work, those are a return to the previously published volumes. Adam, the main protagonist, wanders in jester's crown and a coat, with incense in his hand around courts from which there is no exit displaying his internal disagreement, conducting endless conversations, and commenting on previous conversations and events ${ }^{14}$.

\footnotetext{
${ }^{12}$ Ibidem, p. $97-98$.

${ }^{13}$ AAN, GUKPPiW ref. no. 772 (132/11), 1.96 (104) (double pagination). Review dated 5 Sep 1963.

${ }^{14}$ AAN, GUKPPiW, ref. no. 779 (132/22). Date: 22 Feb 1965.
} 
It is possible that the prefaces and afterwords, with commentary to the changes of the novel's plan, were part of the author's intended strategy aimed at fooling censorship by offering an incorrect temporal placement. If that was the case, the strategy proved ineffective in its very principle. Or rather: it was pointless due to the extreme ideological and "philosophical" generalist nature of Truchanowski's novel, its semantic void, hidden behind an overdeveloped network of symbols. No wonder then that each subsequent volume was treated less serious than the previous one. The conclusion to the review of Zdejmowanie masek, cited before, read:

The criticism of the social system in this volume is more coherent and stinging than in the second one. Yet, since is the author in the afterword set the story in the past, to the deciphering of individual paragraphs seems redundant. I propose to publish this book without any changes ${ }^{15}$.

The censor did regard the criticism as "stinging", but she declined any detailed analysis. She allowed the author to somewhat fall victim to his own strategy: the author's commentary, placing the story in the past (possibly only in order to toy with the censorship) was the only significant cue with which to direct the "stinging criticism" In any way. In fact, the criticism is so veiled and devoid of content that it is insignificant.

It is difficult to assess the amount of influence the game with censorship had on the shape of Mtyny Boże. It was not critical, for sure. Therefore, if we can talk about Aesopian language at all, we can do so in a very specific way. Truchanowski's novel is close to a symbolistic variation of "Aesopiness," characteristic of the Young Poland period. It is related to the poetics of Truchanowski's prose, strongly rooted in the aesthetic patterns of Young Poland. The prose seems to be a late child of that early- $20^{\text {th }}$ century literature. It was a particular stylistic hybrid in which the grotesque coexisted, not very harmoniously, with the epic concept of the work. The influence of Kafka and Schulz mix with Young Poland mannerism, emotionality, with the type of phraseology and imagery characteristic of the period.

Also, the relationship between that prose and censorship proved to include Young Poland patterns. It represented a particular symbolistic variant of "Aesopiness", which consisted, according to Ryszard Nycz, of a shaping of the "semantic structure of the text such that the Aesopian message became one of the many possible (yet equally weak) complex, yet undefined, interpretations and at the same time fundamentally an unclear or undefined conceptual symbolism of the

${ }^{15}$ Ibidem. 
work" ${ }^{\prime 16}$. The censors' reviews of Truchanowski's works quoted without omissions are a testimony to the struggle with such indeterminacy. Initially, it seems to carry serious dangers, as far as state ideology is concerned. However, extended exposure to the prose made the officers disregard the coded, potentially rebellious, ideas considering their hermetic nature, vagueness, lack of strong foundations for any political ideas, or any other, for that matter. In his preface to the first volume, the author himself defined the main issues in the following way: "The most important issue in Mlyny Boże is the tragedy of existence"17. The commentary, formulated with utmost seriousness, leads us to the fundamental problem with Truchanowski's works, suggested in the introduction: the problem of its particular naivety ${ }^{18}$.

In his analysis of the negative influence of censorship on the literature of the Young Poland period, Antoni Potocki pointed to the emergence of a special kind of printable literature, marked by trivial ideas, superficiality, vagueness and conventionality of expression ${ }^{19}$. It was the same case with Truchanowski's works: prose so strictly shaped by literary conventions, burdened with vapid symbolism and marked by intellectual indeterminacy that it was devoid of any political blade. It seems that the initial distrust and curiosity of the censors were more associated with the author himself who, a declared opponent of the system, was under strict control up to a certain point. Gradually, though, Truchanowski underwent subsequent phases of acceptance: from a suspicious author carefully read by censors, he became harmless and accepted, even though with no enthusiasm, to eventually, in the early-1980s, fall under the protection of the authorities.

The "Truchanowski's case" could also be considered as a special kind of "socparnasizm" discussed by Michał Głowiński. It was special because it lacked both the social-political meaning, and pure literary qualities. From today's point of view, the case is unimportant due to its legible artistic value. However, it offers an interesting preliminary study of censorship, depicting some broader processes and phenomena, i.e. the growing pragmatism of the Control Bureau and, in turn, the growing tolerance for poetics and views contrary to official state ideology, and the slowly intensifying ideological indifference of censorship. "The tragedy of existence" that Truchanowski wrote about in the preface to his novel, categorised as "pessimism" by the censors, could not had expected to be approved by the official state policy, but it was acceptable after 1956, provided its roots were sufficiently "universal" and not current.

\footnotetext{
${ }^{16}$ R. Nycz., Literatura polska w cieniu cenzury (wyktad), “Teksty Drugie” 1998, vol. 3, p. 14.

${ }^{17}$ K. Truchanowski, Stowo wstępne, in: Niepokój, Warsaw 1961, p. 6.

${ }^{18}$ Cf. my paper Groteska i antropologia w twórczości Kazimierza Truchanowskiego, "Ruch Literacki” 2010, vol 3.

${ }^{19}$ Cf. R. Nycz, Literatura polska w cieniu cenzury... op. cit., p. 13.
} 


\section{Bibliography}

AAN, GUKPPiW, ref. no. 643 (68/57).

AAN, GUKPPiW, ref. no. $772(132 / 11)$.

AAN, GUKPPiW, ref. no. 779 (132/22).

Chodźko Ryszard, Pejzaże świadomości. Powieściopisarstwo Kazimierza Truchanowskiego, Sekcja Wydawnicza Filii UW, Białystok 1980.

Ficowski Jerzy, Własnowidz i cudotwórca czyli "Ulica Krokodyli" $i$ "Ulica Wszystkich Świętych", "Sanatorium pod Klepsydra”" i “Apteka pod Stońcem”, "Kresy” 1996, No. 2, pp. 61-73.

Gryszkiewicz Bogusław, Adam i panienki. Treści fantazmatyczne w Zatrutych studniach Kazimierza Truchanowskiego, in: Przymierzanie masek. W 100. rocznice urodzin Kazimierza Truchanowskiego, Z. Chlewiński (ed.), Samizdat Zofii Łoś, Płock 2004, pp. 148-159.

Koprowski Jan, Arcydzieło czy mistyfikacja, “Twórczość” 1962, No. 21, pp. 141-143.

Lichański Zdzisław, Kazimierz Truchanowski. Człowiek, pisarz, myśliciel, in: Przymierzanie masek. W 100. rocznicę urodzin Kazimierza Truchanowskiego, Z. Chlewiński (ed.), Samizdat Zofii Łoś, Płock 2004, pp. 70-87.

Mojsak Kajetan, Groteska i antropologia w twórczości Kazimierza Truchanowskiego, "Ruch Literacki" 2010, No. 3 (300), pp. 241-254.

Nycz Ryszard, Literatura polska w cieniu cenzury (wykład), "Teksty Drugie” 1998, No. 3, pp. 5-27.

Truchanowski Kazimierz, Stowo wstępne, in: Niepokój, Państwowy Instytut wydawniczy, Warsaw 1961, pp. 5-6.

Kajetan Mojsak

\section{Politics, Poetics and "the Tragedy of Existence". The Reception of Mryny \\ Boże [the Mills of God] Novel Series by Kazimierz Truchanowski by the \\ Censorship Bureau}

(Summary)

The article analyzes the censorship board's reception of Kazimierz Truchanowski's novel cycle The Mills of the God, published between 1961 and 1967. The analysis gives an insight into the interesting process of the growing tolerance - and indifference - of censorship board towards this kind of hermetic, non-epic prose: far from the official cultural course, but at the same time not coming into open conflict with it. Review of censors' reception of the subsequent parts of Truchanowski's novel can be seen as a contribution to the history of the so-called "socparnasizm" as well as to the history of the growing pragmatism of the censorship board (and its de-ideologization).

Keywords: Truchanowski Kazimierz, The Mills of the God, censorship, censorship towards literature 